\title{
REPORT OF THE SESSION, I9I5-I6.
}

\author{
By A. L. LeACH, F.G.S. \\ (Coninued from page 46. )
}

Ordinary Meeting, Friday, March 3rd, igi6.-George Barrow, F.G.S., M.I.M.M., President, in the Chair.

Alfred Joseph Bull, Mrs. J. F. Colyer, Herbert Lloyd, Miss

Margaret Molloy, and Maurice Albion Ockenden were elected members of the Association.

Mr. V. C. Illing, B.Sc., F.G.S., delivered a lecture entitled "The Oilfields of Trinidad."

\section{[ABSTRACT.]}

A short visit to the Oilfields of Trinidad during the summer of 1915 , led to the collection of material for the correlation of the Tertiary deposits in the south of the island. In addition to the Oilfields, the occurrences of natural hydrocarbons include the Manjak deposits near San Fernando, the lines of mud volcanoes, especially near the south coast, and the famous pitch-lake of $\mathrm{La} \mathrm{Br}$ ea. With regard to the latter phenomenon, certain considerations render doubtful the usually accepted theory of its mode of formation.

The geological succession as shown in the sea-coast sections from La Brea to I cacos, and from Galpha Point eastwards, including the northern, central, and southern anticlines, was examined in detail. An extensive collection of the sedimentary types was made, and the mineral analysis of the samples establish the fact that over the area examined the successive groups of sediments are each characterised by certain exclusive assemblages of heavy minerals.

Ordinary Meeting, Friday, Aprit 7th, 1916.-George Barrow, F.G.S., M.I.M.M., President, in the Chair.

Mrs. E. E. S. Brown was elected a member of the Association.

Mr. M. Odling, F.G.S., read a paper entitled "Notes on the Corallian of the Oxford District, with special reference to the Occurrence of a Pebble-bed at a Constant Horizon," with an Appendix on the "Lithological Character of some Pebbles and Sand Grains from a Pebble-bed in the Corallian of the Oxford District," by Albert Gilligan, B.Sc., F.G.S.

Ordinary Meeting, Friday, May 5th, igi6.-George Barrow, F.G.S., M.I.M.M., President, in the Chair.

John Challinor was elected a member of the Association.

Prof. E. J. Garwood, F.G.S., read a paper entitled " Field Notes on the Faunal Succession in the Lower Carboniferous Rocks of Westmorland and North Lancashire." (See Proceedings, vol. xxvii, p. I.)

Ordinary Meeting, Friday, June 2nd, I916.-George Barrow, F.G.S., M.I.M.M., President, in the Chair.

John Scanes was elected a member of the Association.

Proc. Geol. Assoc., Vol. XXVII, Part 3, 19i6.] 
Dr. P. G. H. Boswell, F.G.S., read a paper entitled "The Petrology of the North Sea Drift and Upper Glacial Brick-earths in East Anglia." (See Proceedings, vol. xxvii, p. 79.)

Miss Mary S. Johnston, F.R.G.S., delivered a lecture entitled "Notes on Erosion Phenomena in Egypt."

\section{[ABSTRACT.]}

Amongst other phenomena of erosion the lecture illustrated the decomposed igneous rocks at the Second Cataract, and the pot-holes and shadewe thering in the granite of the First Cataract. The variation in the constituents of the Nubian Sandstone, the rivers of blown sand on the west of the Nile, and the famous quarries of Gebel Silsileh were also described. Reference was made to interesting geological features of the Theban mountains, notably the Eocene chert concretions, and the dry river-valleys and gravels, and to certain sites from which numerous worked flints have been collected. The action of the sun, wind and water upon the Mokattam limestones was considered in connection with the formation of Wadi Hof and the production of the etched surface of the Sphinx. Fine specimens of split and eroded cherts from Oligocene gravels were shown.

Ordinary Meeting, Friday, July 7 th, i9i6.-George Barrow, F.G.S., M.I.M.M., President, in the Chair.

Mrs. E. Benson, J. E. Wynfield Rhodes, E. Spencer and John Spencer were elected members of the Association.

Prof. T. Franklin Sibly delivered a lecture entitled "The Geology and Scenery of the Cardiff District."

\section{[ABSTRACT.]}

Outline of the Stratigraphy and Geological Structure of the District.-The Palæozoic rocks (Silurian to Carboniferous) in the Cowbridge-Cardiff anticline and the syncline of the coalfield. The Mesozoic strata (Keuper, Rhætic, and Lias) in the Vale of Glamorgan; remarkable development of littoral deposits. Glacial, estuarine, and alluvial deposits.

Physical Features and Scenery.-The coast-line from Porthcawl to Penarth : sand-dunes, shingle beaches, and cliffs. The coastal lowlands of Lias and Old Red Sandstone. The rim of the coalfield from Abergavenny to Cardiff, its scarps, strike-valleys, and gorges. The coalfield plateau of Pennant Grit, and its valleys. Waterfalls and underground watercourses in the valleys of the north crop. 